Brit. J. vener. Dis. (1963), 39, 101.

\title{
SOME CURRENT ASPECTS OF THE EPIDEMIOLOGY OF GONORRHOEA*
}

\author{
BY \\ S. M. LAIRD \\ St. Luke's Clinic and V.D. Department, Royal Infirmary, Manchester
}

Gonorrhoea in the adult is a venereal infection of the lower genito-urinary tract due to Neisseria gonorrhoeae. It occurs most commonly amongst promiscuous persons in the larger urban communities.

Incubation Period.-In the male this is short, symptoms developing in three-quarters of all cases from 2 to 6 days inclusive after infection (Laird, 1958); in a few patients, however, it appears genuinely to exceed 10 days. It is my impression that, in the same individual, the incubation period in subsequent attacks may be longer than in the first attack. The incubation period in the female is difficult to study but is probably similar to that in the male.

Clinical Picture.-In men, the gonococcus produces an acute urethritis manifest by a purulent urethral discharge and a pus haze with shreds in the first glass of the two-glass urine test. These characteristic features will be modified if the patient has urinated shortly before the examination. This important practical point - the time elapsing between the last urination and the examination-should never be neglected.

In the female, the urethra and cervix uteri are the two main sites for attack by the gonococcus. Involvement of the urethra is usually short-lived and is seldom found except in the recently-infected acute case. The clinical picture in the female varies greatly; a purulent urethritis and cervicitis may be seen in some recently-infected women, but the majority of cases show so few clinical manifestations that the infection is best described as asymptomatic or latent. As with recent urination in the male, douching by the female patient before leaving home for examination in the clinic may modify both the clinical picture and the results of laboratory tests.

\footnotetext{
* Paper read to the M.S.S.V.D. on November 30, 1962.
}

In these largely asymptomatic cases, unless infection is suspected on epidemiological grounds, the patient is unlikely to seek medical advice until complications, such as salpingitis or Bartholinian abscess, have produced painful symptoms. These asymptomatic carriers make up the reservoir of infection in the community and this is the basic factor responsible for our failure to control gonorrhoea as a public health problem.

Diagnosis.-The diagnosis of gonorrhoea, or its exclusion, must clearly rest on the results of bacteriological tests. In general, a Gram-stained smear of urethral discharge is adequate in men, but cultures from the urethra and cervix are essential in the female. I do not think that tests from the rectum are required routinely in women, though our proctoscope is already in frequent demand for the examination of passive male homosexuals! Attention to detail in the collection of specimens, staining, and cultural methods is essential if the best possible results are to be obtained, and these points have recently been well described by Wilkinson (1962). The complement-fixation test (G.C.F.T.) on serum has no place in the diagnosis of uncomplicated gonorrhoea and is seldom of value even in the patient with complications. Fluorescent antibody techniques, although stated to be promising, are not yet established procedures. Neisseria, other than $N$. gonorrhoeae, occur so rarely in the lower genitourinary tract that they seldom constitute a practical problem in diagnosis.

Immunity and Infectivity.-Gonococcal infection seldom, if ever, produces any significant immune response. I have seen a man who claimed to have had a urethral discharge for just over 12 months and examination showed a subacute urethritis with typical gonococci in the smear. Certainly, after successful antibiotic treatment, there is no immunity 
to re-infection. In the pre-sulphonamide era, gonococci persisted for months in spite of local treatment but presumably died out eventually.

The gonococcal complement-fixation test, even when reliably performed, throws little light on the immunological situation. With effective antibiotic treatment applied early in the course of the infection, as in the majority of male cases, it has little opportunity to become positive. In cases with more deeplyseated infection, e.g. salpingitis, a positive result may be found. On the other hand, in some patients, a positive result may persist for years after other evidence of active infection has disappeared and its significance is difficult to determine.

In women, gonorrhoea is still frequently a chronic infection, and the woman may be infectious only intermittently, especially with alcohol or orgasm or immediately after a menstrual period; in such women, the diagnosis of gonorrhoea can be very difficult and false-negative results are not uncommon. It seems clear, also, that the male can transmit gonorrhoea during the incubation period and before the appearance of urethral discharge.

In spite of the absence of encouraging immunological features, I still believe with Morton that research should be directed towards the possibility of developing a vaccine for the immunization of selected groups of the population (Laird and Morton, 1959). If a practical method of immunization could be developed, it would have its main application in countries of high incidence. However, it would also be of value here in certain large towns in view of the high proportion of immigrants who become infected, the high rate of "repeat" infections, the ability of some strains of gonococci to resist various antibiotic treatments, and the risk of patients becoming increasingly drug-sensitive.

Treatment.-For almost a decade procaine penicillin, in low dosage, proved to be a safe and rapid cure for gonorrhoea. In the past 5 years, however, the emergence of less sensitive strains of gonococci has become widely recognized (Curtis and Wilkinson, 1958; Cradock-Watson, Shooter and Nicol, 1958; King, 1958; Reyn, Korner, and Bentzon, 1958; Reyn, 1961, Durel, 1961). In the same period gonorrhoea resistant to streptomycin has also become increasingly common (Alergant, 1958; Durel, 1961). The M.R.C. Working Party (1961) has shown that the incidence of these less sensitive strains varies from place to place and even from time to time in the same place.

These reports suggested to me that neither P.A.M. nor aqueous procaine penicillin preparations (in a single injection of 600,000 units) were able to cure infections with strains of gonococci whose minimum inhibitory concentration (m.i.c.) with penicillin was 0.25 units $/ \mathrm{ml}$. or higher. For the past 4 years we in Manchester have accordingly treated gonorrhoea with a combination of aqueous procaine penicillin and crystalline penicillin $G$ in a proportion of $3: 1$ (Avloprocil N.A.), giving a single injection of 800,000 units to males and of $1 \cdot 2$ megaunits to females. It was hoped that, in association with procaine penicillin, the initially high but short-lived blood level provided by the crystalline penicillin would prove effective against strains of higher m.i.c. This treatment regime has given fairly satisfactory results. However, as it has been shown (M.R.C. Working Party, 1961) that the sensitivity pattern varies not only from place to place but also from time to time in the same place, a small study was carried out in August and September 1962. Male cases of gonorrhoea diagnosed on Tuesdays were treated with one injection of 900,000 units aqueous procaine penicillin and the results were compared with those in men treated on Mondays with 800,000 units Avloprocil N.A. It will be noted (Table I) that the racial composition of the two groups is essentially similar. Patients who did not return were classified as presumed cures, and those who on examination 7 days after treatment were free from discharge and had a clear urine were regarded as clinical cures. The remaining cases still had evidence of gonorrhoea 7 days after treatment and were recorded as failures. The distinction between true failure and re-infection within 7 days of treatment is frequently difficult, and sometimes impossible, but a tentative distinction between true failure and

TABLE I

COMPARISON OF RESULTS IN MALE CASES OF GONORRHOEA TREATED WITH 900,000 UNITS PROCAINE PENICILLIN OR 800,000 UNITS AVLOPROCIL N.A.

\begin{tabular}{|c|c|c|c|c|c|c|}
\hline \multicolumn{5}{|c|}{ Treatment Schedule } & $\begin{array}{c}900,000 \text { u. } \\
\text { Procaine } \\
\text { Penicillin }\end{array}$ & $\begin{array}{l}800,000 \text { u. } \\
\text { Avloprocil } \\
\text { N.A. }\end{array}$ \\
\hline \multirow[t]{2}{*}{$\begin{array}{l}\text { Country of } \\
\text { Origin of } \\
\text { Patients }\end{array}$} & \multicolumn{2}{|c|}{$\begin{array}{l}\text { United Kingdom } \\
\text { West Indies } \\
\text { West Africa } \\
\text { Eire } \quad . . \\
\text { Other } \quad . .\end{array}$} & $\begin{array}{l}\cdots \\
\cdots \\
\cdots \\
\cdots\end{array}$ & $\begin{array}{l}\ldots \\
\cdots \\
\cdots\end{array}$ & $\begin{array}{r}35 \\
28 \\
4 \\
16 \\
5\end{array}$ & $\begin{array}{r}36 \\
23 \\
9 \\
9 \\
14\end{array}$ \\
\hline & \multicolumn{2}{|l|}{ Total } & $\ldots$ & . & 88 & 91 \\
\hline \multirow{2}{*}{ Results .. } & Cure & $\begin{array}{l}\text { Clinic } \\
\text { Presu }\end{array}$ & $\begin{array}{l}\text { cal } \\
\text { imed }\end{array}$ & . & $\left.\begin{array}{l}54 \\
23\end{array}\right\} 77$ & $\left.\begin{array}{l}54 \\
28\end{array}\right\} 82$ \\
\hline & Failure & \multicolumn{3}{|c|}{$\begin{array}{l}\text { Presumed True } \\
\quad \text { Failure } \quad . . \\
\text { Probable } \\
\text { Re-infection }\end{array}$} & $\left.\begin{array}{l}9 \\
2\end{array}\right\} 11$ & $\left.\begin{array}{l}4 \\
5\end{array}\right\} 9$ \\
\hline
\end{tabular}


probable re-infection has been attempted. It will be seen that the results in the two treatment groups were roughly similar, but that what difference there was favoured the Avloprocil N.A. schedule.

It is not practicable to carry out cultures before treatment, but cultures are performed in patients who still show microscopical evidence of gonorrhoea on their first post-treatment attendance which is usually 7 days after therapy. The results of cultures in the comparative study are shown in Table II. Unfortunately the m.i.c. of penicillin could only be determined in nine cases (in the others, no growth occurred in primary culture or the organism died on sub-culture) but the m.i.c. was high in all cases. Three patients who failed with 900,000 units procaine penicillin were cured with 800,000 units Avloprocil N.A., and in two of these the m.i.c. of penicillin was 0.5 units $/ \mathrm{ml}$.

TABLE II

PENICILLIN SENSITIVITY (M.I.C.) OF GONOCOCCUS IN FAILURES

\begin{tabular}{c|c|c}
\hline \multirow{3}{*}{ m.i.c. } & \multicolumn{2}{|c}{ Dosage Schedule of Penicillin } \\
\cline { 2 - 3 } & $\begin{array}{c}900,000 \text { units } \\
\text { Procaine Penicillin }\end{array}$ & $\begin{array}{c}800,000 \text { units } \\
\text { Avloprocil N.A. }\end{array}$ \\
\hline $\begin{array}{c}0.25 \\
0.5\end{array}$ & 0 \\
No result & 4 & 3 \\
& 7 & 2 \\
\hline
\end{tabular}

The treatment of gonorrhoea in our patients, many of whom are unreliable and promiscuous, must ideally remain a "one-shot" remedy, and I believe that penicillin is still the antibiotic of choice. However, the particular preparation used is important and procaine penicillin alone has probably had its day. A combination of crystalline penicillin and procaine penicillin (e.g. Avloprocil N.A.), perhaps in larger dosage than that reported above, seems to be satisfactory.

Re-treatment of Failures. - This is a problem of increasing importance. Where procaine penicillin has failed, stroptomycin is most unlikely to be effective. Injectable tetracyclines produce local discomfort in many patients and their efficacy in penicillin-failures is unknown. Actinospectacin (Trobicin) in one injection has given good preliminary results (Laird and Taylor, 1962; Willcox, 1962), but it is not so far commercially available and I noted some evidence to suggest that the gonococcus could quickly develop increased resistance to it. Orally administered tetracyclines and sulphonamides are effective in some cases but, in addition to possible side-effects, have in principle all the objections of any oral regime for unsupervised and often careless outpatients.
Theoretically, sufficient penicillin can be given to overcome the less sensitive strains of gonococci, and I believe that the treatment of initial failures should comprise more penicillin in higher dosage. Unfortunately, multiple injections for 48 to 72 hours will be necessary and thus we are reaching full cycle in the penicillin treatment of gonorrhoea.

Treatment of Females.-While the infected male usually reports promptly for diagnosis and treatment, it is often difficult to get the infected female to the clinic and accurate bacteriological diagnosis must frequently await the culture results. In Manchester, at least, the first visit may also be the last in a significant proportion of these young women, and I believe that the case for immediate "epidemiological" treatment is clear-cut. It is also very important to use a single treatment which achieves cure in as near to 100 per cent. of cases as possible; the male in whom treatment has failed will return but the female has little or no clinical indication of the outcome of her treatment and many fail to attend for tests of cure. It is for these reasons that I use a larger dosage of penicillin in the female and why I have devoted a considerable part of this talk to this aspect of treatment.

Post-treatment Follow-up.-With a treatment failure-rate of 10 per cent. or more, the need for follow-up is obvious. Where possible, it may now be desirable to see male cases in 3 or 4 rather than 7 days after treatment. It is important to examine the patient for the presence of discharge and not just accept his statement that it has cleared up. It is also essential to drive home to male patients that they must refrain from urination for at least 3 hours before their follow-up visits. In all cases the prostatic secretion must be examined and in the older patient, or in persons with previous infections, urethral stricture should be excluded. In the female postmenstrual examinations are most important, but unfortunately a high rate of early default in both sexes often precludes the careful follow-up that one desires.

Age and Race.-The importance of the age and country of origin of patients in the epidemiology of gonorrhoea has been considered on a large population scale in recent reports by the British Clinical Co-operative Group, and I have described the situation in the Manchester area on several occasions in the past 5 years (Laird, 1958; Laird and Morton, 1959; Laird, 1961, 1962a, 1962b). From recent detailed studies of the position in the City of Manchester (Laird, 1962a) and in the peripheral clinics of the Manchester Regional Hospitals Board Area 
(Laird, 1962b), the following facts deserve emphasis:

(1) In Manchester, gonorrhoea infections in males born in the U.K. have not increased since 1955 and the total in 1961 was only 70 per cent. of that of 1951 .

(2) In about half of the female teenagers with gonorrhoea who attended St. Luke's Clinic with contact slips, the male consorts were immigrants and predominantly coloured ones.

(3) In those peripheral clinics in which the total of male gonococcal infections showed recent increase, this increase occurred only after immigrants (West Indians and/or Pakistanis) had settled in the area; increased infection amongst female teenagers occurred chiefly in the same areas. The presence of immigrants in a locality thus leads, both directly and indirectly, to an increased incidence of gonorrhoea in both sexes.

(4) The marked increase in gonorrhoea infections since 1955 would not have occurred if large-scale immigration had not taken place.

The Future.-Whilst prophecy may be foolish, it is equally unwise not to try to assess the probable caseload for the clinics in the next decade. In Manchester the case-load will depend largely on two main factors: the rate at which immigration continues, and the sexual behaviour of the local females who are entering the teenage and 20 to 24-year age groups. In the longer term, a third factor of significance will be the sexual pattern adopted by the children of mixed parentage at present being fathered by our immigrants from overseas.

\section{Summary}

Gonorrhoea occurs most commonly amongst promiscuous persons in the larger urban communities.

The largely asymptomatic character of infection in the female means that only those with painful complications and those brought to the clinic as a result of epidemiological effort, will be treated, hence the female "reservoir" of infection which makes the control of gonorrhoea, as a public health problem, impossible. Immediate "epidemiological" treatment at the first visit is generally indicated.

The decreasing efficacy of procaine penicillin requires us to consider what is now the best preparation of penicillin and its optimum dosage. The therapy of treatment-failures also requires careful study. Post-treatment follow-up is once again of great importance, but is frequently impossible because of the high rate of early default in both sexes.
In Manchester, gonorrhoea infections in men born in the U.K. have not increased since 1955, and it is known that, in at least half the infected female teenagers, the male consorts were immigrants. It is suggested that the marked increase in gonorrhoea infections since 1955 would not have occurred in the absence of large-scale immigration.

\section{REFERENCES}

Alergant, C. D. (1958). Brit. J. vener. Dis., 34, 36.

Cradock-Watson, J. E., Shooter, R. A., and Nicol, C. S. (1958). Brit. med.J., 1, 1091.

Curtis, F. R. and Wilkinson, A. E. (1958). Brit. J. vener. Dis., 34, 70

Durel, P. (1961). Ibid., 37, 107.

King, A. J. (1958). Lancet, 1, 651.

Laird, S. M. (1958). Brit. J. vener. Dis., 34, 137. (1961). Ibid., 37, 70.

(1962a). Ibid., 38, 134.

(1962b). Ibid., 38, 181

and Morton, R. S. (1959). Ibid., 35, 187. and Taylor, G. (1962). Ibid., 38, 60.

Medical Research Council Working Party (1961). Lancet, 2, 226.

Reyn, A. (1961). Brit. J. vener. Dis., 37, 145.

Korner, B., and Bentzon, M. W. (1958). Ibid., 34, 227.

Wilkinson, A. E. (1962). Ibid., 38, 145.

Willcox, R. R. (1962). Ibid., 38, 150.

\section{Epidémiologie de la blennorragie RÉSUMÉ}

On rencontre la blennorragie le plus souvent parmi les personnes promiscues des grandes villes. Parce que l'infection est presque toujours asymptomatique chez les femmes, seulement celles qui sont atteintes de complications pénibles ou qui sont découvertes par les recherches épidémiologiques peuvent être traitées. De là l'origine du réservoir d'infection chez les femmes qui rend impossible le contrôle de la blennorragie par le service sanitaire. Il est donc nécessaire de traiter les femmes tout de suite à la première consultation sans attendre que le diagnostic soit confirmé.

Puisque la pénicilline devient de plus en plus inefficace, il faut choiser avec soin la meilleure préparation et le dosage optimum. Il faut aussi étudier le traitement des cas réfractaires, et suivre ceux qui semblent guérir. Cependant cette dernière précaution est souvent impossible, du fait que nombreux individus des deux sexes ne reviennent pas à la clinique.

A Manchester le nombre d'infections parni les hommes nés au Royaume-Uni n'a pas augmenté depuis 1955, et la moitié des jeunes filles de moins de 20 aus trouvent leurs partenaires sexuels parmi les immigrants.

On constate que l'augmentation des infections gonococciques remarquée depuis 1955 n'aurait pas eu lieu sans l'immigration en masse des gens d'outre-mer. 